\title{
THE ROLE OF CT IN ABDOMINAL TRAUMA
}

\section{Doctor Iftikhar Mahmood}

I

$\mathrm{n}$ this issue of the Russian electronic journal of radiology, we present the lecture of Professor Iftikhar Mahmood on relevant and important topic - the use of computed tomography in the diagnosis of abdominal trauma. The lecture marks the most important radiological signs, which are critical on making the decision of the character and size of surgical treatment.

Keywords: MSCT, abdominal trauma, computed tomography, emergency radiology.

\section{РОАЬ КОМПЬЮТЕРНОЙ ТОМОГРАФИИ В АИАГНОСТИКЕ АБАОМИНААЬНОЙ TPABMЫ}

\author{
Иортихар Махмуа
}

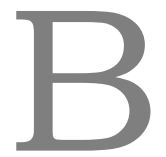

рамках этого номера российского эмектронного журнала мучевой диагностики мы представцяем мекцию профессора Ифтихара Махмуда на актуальную и важную тему - применение компьютерной томографии в диагностике травм брюшной полости. В цекции обозначены наиболее важные рентгенологические признаки, которые существенно влияют на принятие решения о характере и объеме хирургического вмешательства у данной группы пациентов.

Ключевые слова: МСКТ, абдоминальная травма, компьютерная томография, экстренная радиология. 


\title{
А^я просмотра мастер-к^асса перейАите на сайт:
}

https://rejr.ru/twenty-five_nomer/master-class.html\%20

\author{
Dr. Iftikhar Mahmood \\ Consultant Radiologyst \\ Earling Hospital, London UK
}

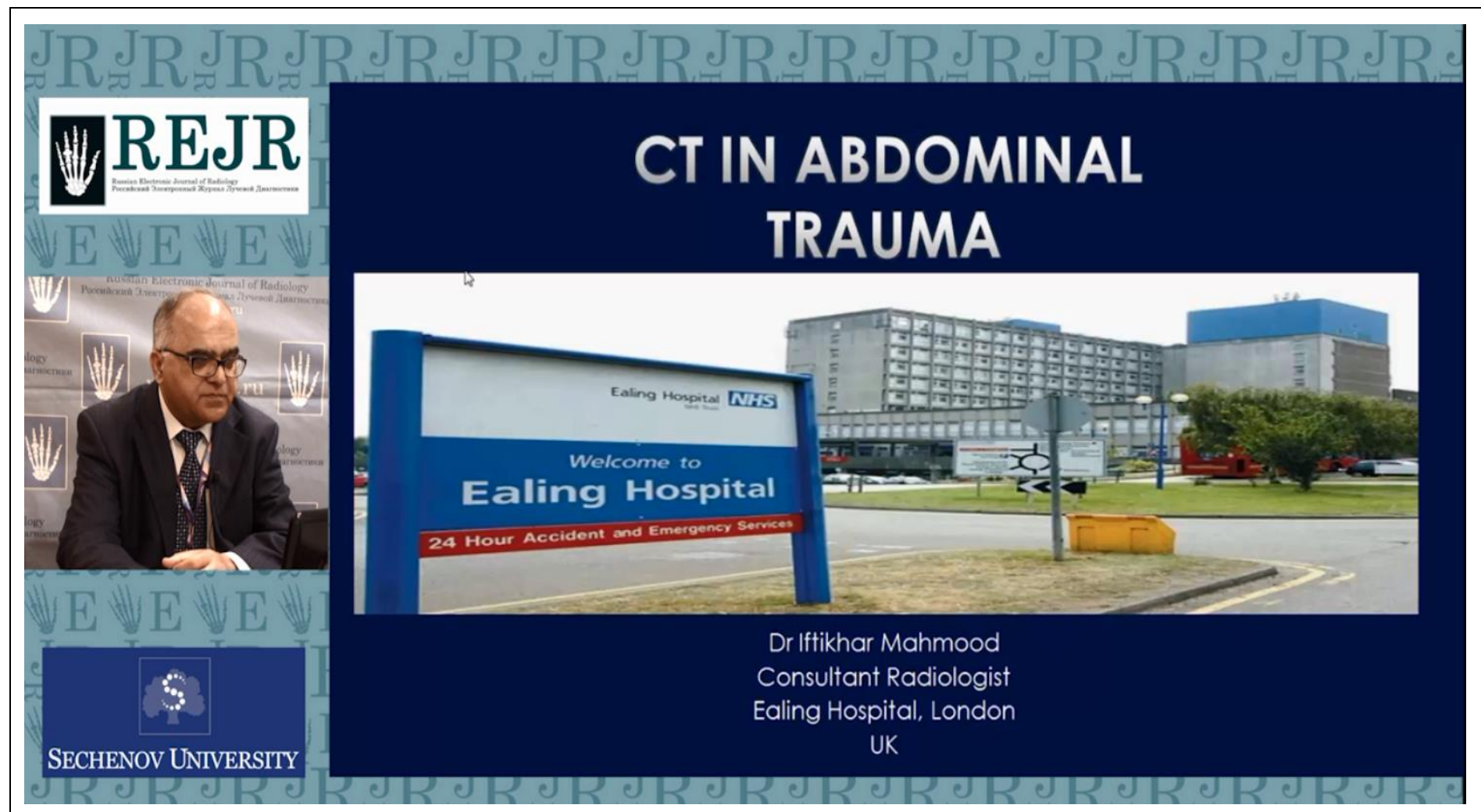

\section{Мастер-к^acc. THE ROLE OF CT IN ABDOMINAL TRAUMA}

А^я запуска презентации нажмите на ^юбое место в области презентации, чтобы она загрузилась (если Вы просматриваете журнал в окне браузера, то вначале сохраните журна^ к себе на компьютер и откройте его с $о$ кального Аиска, иначе презентация не пойдет).

1) Используйте кнопки влево и вправо в левом нижнем углу страницы Аля перемещения по слайлам.

2) КажАая презентация сопровожАается текстовым или звуковым комментарием автора. Включите в верхнем левом угАу третью вКАаАКУ - ЗАМЕТКИ. САеАите за текстом автора при перекАючении презентации на новый слайА. Если презентация сопровождается звуком, то отрегулируйте уровень звука, нажав на иконку Аинамика.

3) Чтобы вкАючить полноэкранный просмотр презентации Аостаточно нажать Аевой кнопкой мыши на правую нижнюю кАавишу перехода в полноэкранный режим.

Если у Вас не отображается мастер-к^асс - установите Adobe Flash Player: http://get.adobe.com/ru/flashplayer/

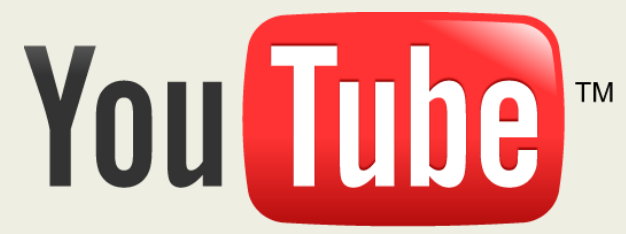

Внимание! Презентация защищена авторскими правами. Полное ияи частичное копирование материала запрещено, без преАварительного согласия авторов. 